\title{
SEMANTIC CLUSTERING DAN PEMILIHAN KALIMAT REPRESENTATIF UNTUK PERINGKASAN MULTI DOKUMEN
}

\author{
Pasnur $^{1}$, Putu Praba Santika ${ }^{2}$ Gus Nanang Syaifuddin ${ }^{3}$ \\ 1,2,3 Jurusan Teknik Informatika, Institut Teknologi Sepuluh Nopember \\ Kampus ITS Keputih, Sukolilo, Surabaya 60111, Jawa Timur, Indonesia \\ Email: 1pasnur13@mhs.if.its.ac.id, ${ }^{2}$ praba13@mhs.if.its.ac.id, ${ }^{3}$ gusnanang13@mhs.if.its.ac.id
}

(Naskah masuk: 11 Juni 2014, diterima untuk diterbitkan: 22 Juli 2014)

\begin{abstract}
Abstrak
Coverage dan saliency merupakan masalah utama dalam peringkasan multi dokumen. Hasil ringkasan yang baik harus mampu mampu mencakup (coverage) sebanyak mungkin konsep penting (salient) yang ada pada dokumen sumber. Penelitian ini bertujuan untuk mengembangkan metode baru peringkasan multi dokumen dengan teknik semantic clustering dan pemilihan kalimat representatif cluster. Metode yang diusulkan berdasarkan prinsip kerja Latent Semantic Indexing (LSI) dan Similarity Based Histogram Clustering (SHC) untuk pembentukan cluster kalimat secara semantik, serta mengkombinasikan fitur Sentence Information Density (SID) dan Sentence Cluster Keyword (SCK) untuk pemilihan kalimat representatif cluster. Pengujian dilakukan pada dataset Document Understanding Conference (DUC) 2004 Task 2 dan hasilnya diukur menggunakan Recall-Oriented Understudy for Gisting Evaluation (ROUGE). Hasil pengujian menunjukkan bahwa metode yang diusulkan mampu mencapai nilai ROUGE-1 rata-rata sebesar 0,395 dan nilai ROUGE-2 rata-rata sebesar 0,106.
\end{abstract}

Kata kunci: peringkasan multi dokumen, latent semantic indexing, similarity based histogram clustering, sentence information density, sentence cluster keyword

\begin{abstract}
Coverage and saliency is a major problem in multi-document summarization. The good summary should be able to cover (coverage) as much as possible the important concepts (salient) that exist in the source document. This research aims to develop a new method for multiple document summarization with semantic clustering techniques and the selection of representative clusters sentence. The proposed method is based on the principles of Latent Semantic Indexing (LSI) and Similarity Based Histogram Clustering (SHC) for clustering sentences semantically, and combine features of Sentence Information Density (SID) and Sentence Cluster Keyword (SCK) for selecting a representative sentence cluster. Tests are performed on Document Understanding Conference (DUC) 2004 Task 2 dataset and the results are measured using the Recall-Oriented Understudy for Gisting Evaluation (ROUGE). The results show that the proposed method is able to achieve ROUGE-1 value by an average of 0.395 and the ROUGE-2 value by an average of 0.106 .
\end{abstract}

Keywords: multiple document summarization, latent semantic indexing, similarity based histogram clustering, sentence information density, sentence cluster keyword

\section{PENDAHULUAN}

Perkembangan World Wide Web (WWW) diikuti dengan pertumbuhan jumlah dokumen digital yang sangat pesat. Hal tersebut menimbulkan permasalahan dalam pencarian dan peringkasan informasi dari berbagai sumber (Sarkar, 2009). Peringkasan yang dilakukan secara manual oleh manusia tidak efisien karena jumlah dokumen yang sangat besar (Gupta \& Lehal, 2010).

Peringkasan multi dokumen secara otomatis menjadi perhatian pada beberapa penelitian (Sarkar, 2009; Kogilavani \& Balasubramani, 2010; Ouyang, Li, Zhang, Li, \& Lu, 2012) sebagai sebuah solusi dalam peringkasan dengan kondisi jumlah dokumen yang sangat banyak (Sarkar, 2009). Peringkasan multi dokumen secara otomatis menghasilkan bentuk dokumen yang lebih ringkas tanpa kehilangan kandungan informasi yang penting (Gupta \& Lehal, 2010).

Coverage dan saliency merupakan masalah utama dalam peringkasan dokumen. Hasil Ringkasan yang baik adalah ringkasan yang mampu mencakup (coverage) sebanyak mungkin konsep penting (salient) yang ada pada dokumen sumber (Ouyang, Li, Zhang, Li, \& Lu, 2012). Hasil ringkasan harus mampu memilih kalimat-kalimat utama (penting) dan terhindar dari redundansi (redundancy) sehingga mampu mencakup banyak konsep.

Beberapa penelitian telah mengusulkan metode untuk mengatasi persoalan coverage dan saliency. Penelitian (Sarkar, 2009) menggunakan pendekatan clustering kalimat untuk menghasilkan cakupan ringkasan yang baik. Penelitian $(\mathrm{He}, \mathrm{Li}$, Shao, Chen, 
\& Ma, 2008) menggunakan fitur kepadatan informasi untuk menentukan kalimat yang menjadi representatif cluster untuk menyusun hasil ringkasan. Penelitian (Suputra, Arifin, \& Yuniarti, 2013) mengkombinasikan metode pada penelitian (Sarkar, 2009) dan (He, Li, Shao, Chen, \& Ma, 2008) untuk menghasilkan peringkasan multi dokumen yang lebih baik.

Clustering kalimat merupakan suatu metode yang mampu memberikan good coverage pada ringkasan (Sarkar, 2009). Pencapaian good coverage pada ringkasan tidak terlepas dari koherensi cluster yang baik. Salah satu metode yang dapat menjamin koherensi cluster adalah SHC. Metode tersebut pertama kali diusulkan oleh penelitian (Hammouda \& Kamel, 2003) kemudian diterapkan pada penelitian (Sarkar, 2009) dan (Suputra, Arifin, \& Yuniarti, 2013).

Strategi pemilihan kalimat representatif menjadi sangat penting untuk memecahkan masalah saliency. Kalimat yang terpilih harus mampu mewakili topik dari suatu cluster tertentu (Sarkar, 2009). Kalimat penting penyusun ringkasan harus memiliki kepadatan informasi yaitu mengandung informasi sebanyak mungkin dari dokumen sumber. Fitur SID merupakan sebuah usulan untuk menentukan tingkat kepadatan informasi tersebut (He, Li, Shao, Chen, \& Ma, 2008).

Penelitian (Suputra, Arifin, \& Yuniarti, 2013) mengatasi permasalahan coverage dan saliency sekaligus dengan mengusulkan sebuah framework untuk peringkasan multi dokumen. Pembentukan cluster kalimat dilakukan dengan $\mathrm{SHC}$, sedangkan pemilihan kalimat represetatif cluster dilakukan dengan kombinasi fitur SID dan SCK.

Perhitungan similaritas kalimat dalam penentuan keanggotaan cluster yang dilakukan pada penelitian (Suputra, Arifin, \& Yuniarti, 2013) menggunakan Uni Gram Matching Based Similarity. Metode tersebut mempertimbangkan kesamaan term yang dipakai secara bersama pada dua buah kalimat yang akan dihitung kemiripannya.

Pada kenyataannya, terdapat kemungkinan kemunculan kata-kata yang sinonim pada kedua kalimat yang dibandingkan. Salah satu contoh yang dapat menjelaskan konsep sinonim adalah kata car dan automobile. Kedua kata tersebut memiliki makna yang sama tetapi bentuk kata yang berbeda. Jika kedua kata tersebut diukur menggunakan metode usulan penelitian (Suputra, Arifin, \& Yuniarti, 2013), maka nilai similaritasnya rendah, padahal keduanya memiliki hubungan semantik yang tinggi. Sehingga perhitungan similarity kalimat perlu mempertimbangkan kemungkinan hubungan semantik tersebut. Penelitian (Song \& Park, 2009) mengusulkan penggunaan LSI untuk menemukan relasi semantik yang tersembunyi pada kasus text clustering.

Penelitian ini bertujuan untuk mengembangkan metode baru peringkasan multi dokumen dengan

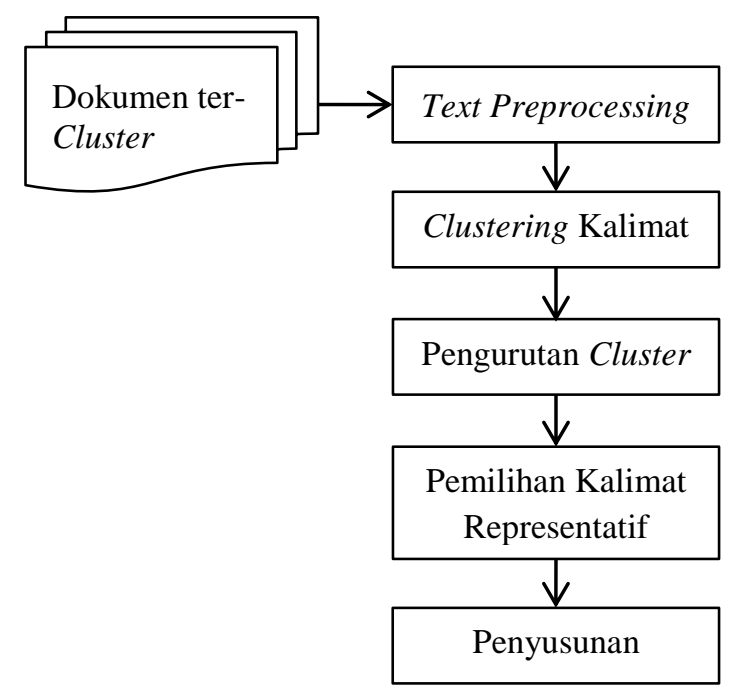

Gambar 1. Framework Peringkasan Multi Dokumen.

teknik semantic clustering dan pemilihan kalimat representatif cluster. Metode yang diusulkan berdasarkan prinsip kerja LSI dan SHC untuk pembentukan cluster kalimat secara semantik, serta mengkombinasikan fitur SID dan SCK untuk pemilihan kalimat representatif cluster.

\section{METODE}

Metode yang digunakan pada penelitian ini menggunakan framework yang diadopsi dari penelitian (Sarkar, 2009) seperti yang ditunjukkan pada Gambar 1. Terdapat 5 tahapan yang digunakan, yaitu: text preprocessing, clustering kalimat, pengurutan cluster, pemilihan kalimat representatif, dan penyusunan ringkasan. Dokumen input yang akan diolah telah dikelompokkan ke dalam berbagai cluster.

\subsection{Text Preprocessing}

Text preprocessing merupakan tahapan pertama yang dilakukan sebelum input dokumen diolah lebih lanjut menjadi cluster-cluster kalimat. Proses-proses yang dilalui dalam tahap text preprocessing adalah segmentation, stopword removal dan stemming. Penelitian ini melakukan segmentasi terhadap kata dan kalimat. Setiap kata yang diperoleh dari hasil segmentasi menjadi input pada proses stopword removal untuk menghilangkan kata-kata yang tidak memiliki arti signifikan dalam proses pembentukan cluster. Pada bagian akhir dilakukan proses stemming dengan algoritma Porter Stemmer untuk mendapatkan bentuk kata dasar.

\subsection{Clustering Kalimat}

Hasil dari text processing akan menjadi input untuk melakukan pembentukan cluster kalimat. Bagian ini memiliki peran penting dalam sistem peringkasan otomatis. Setiap topik dalam dokumen 


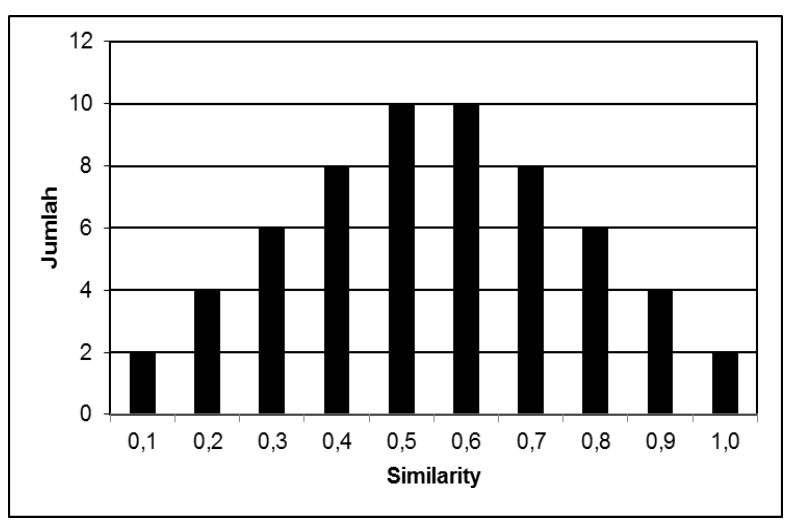

Gambar 2. Cluster Similarity Histogram.

harus diidentifikasi secara tepat untuk menemukan similarity dan dissimilarity yang ada dalam dokumen sehingga menjamin good coverage (Sarkar, 2009).

Koherensi cluster merupakan sebuah faktor yang sangat penting untuk menjamin kualitas hasil ringkasan. Koherensi cluster menunjukkan keterkaitan antar kalimat pada masing-masing cluster yang terbentuk dalam proses peringkasan multi dokumen. Derajat koherensi cluster yang tinggi sangat sulit dicapai karena memerlukan pengetahuan tentang makna dan struktur kalimat (Sarkar, 2009).

Penelitan ini menggunakan metode $S H C$ yang mampu menjaga koherensi dari cluster yang terbentuk. Dalam SHC diperkenalkan konsep cluster similarity histogram. Konsep tersebut merupakan representasi statistik dari suatu distribusi similarity pasangan antar anggota yang ada pada suatu cluster. Jumlah dari bin dalam histogram menunjukkan interval nilai similarity tertentu (Sarkar, 2009; Hammouda \& Kamel, 2003).

Derajat koherensi yang tinggi dalam sebuah cluster dapat dicapai dengan cara mempertahankan derajat similarity antar anggota tetap tinggi (Sarkar, 2009; Hammouda \& Kamel, 2003). Dalam konsep similarity histogram, hal tersebut berarti menjaga distribusi similarity agar cenderung ke kanan. Ilustrasi konsep $S H C$ tersebut dapat dilihat pada Gambar 2.



Gambar 3. Representase Vektor Pada Pengukuran Cosine Similarity.
Penentuan similarity antar kalimat dalam pembentukan cluster menggunakan prinsip kerja dari metode $L S I$, yang berfungsi untuk menemukan relasi semantik yang tersembunyi (Song \& Park, 2009). LSI mengikuti logika bahwa kata-kata yang digunakan dalam konteks yang sama cenderung memiliki makna semantik yang sama. Salah satu sifat utama LSI adalah kemampuannya untuk membangun hubungan antara istilah yang muncul dalam konteks yang serupa.

Metode LSI membutuhkan proses Singular Value Decomposition (SVD) terhadap matriks yang dihasilkan dari Vector Space Model (VSM) antara term dan kalimat. Nilai VSM yang diwakili oleh matriks $\mathrm{X}$ akan didekomposisi menjadi tiga buah matriks U, $\sum$, dan V, sehingga memenuhi Persamaan (1). Matriks U dan V merupakan matriks singular kiri dan kanan, sedangankan matriks $\sum$ merupakan matriks diagonal yang menunjukkan nilai singular.

$$
X=U \cdot \sum \cdot V^{T} \text {. }
$$

Pengukuran nilai similarity yang digunakan adalah cosine similarity, yaitu perhitungan tingkat kemiripan berdasar pada besar sudut kosinus antara dua vektor seperti pada Gambar 3. Vektor kalimat pertama dinotasikan dengan vektor $\mathrm{v}_{1}$ dan vektor kalimat kedua dinotasikan dengan $v_{2}$. Kedua vektor kalimat tersebut digambarkan pada bidang datar sumbu $\mathrm{x}$ dan sumbu y. Berdasarkan kosinus sudut antara dua vektor $(\delta)$, maka nilai similarity berkisar antara 0 sampai dengan 1 . Nilai 0 menandakan bahwa kedua kalimat yang dibandingkan tidak mirip sama sekali, sedangkan nilai 1 menandakan bahwa kedua kalimat yang dibandingkan benar-benar identik.

Penentuan keanggotaan cluster kalimat harus

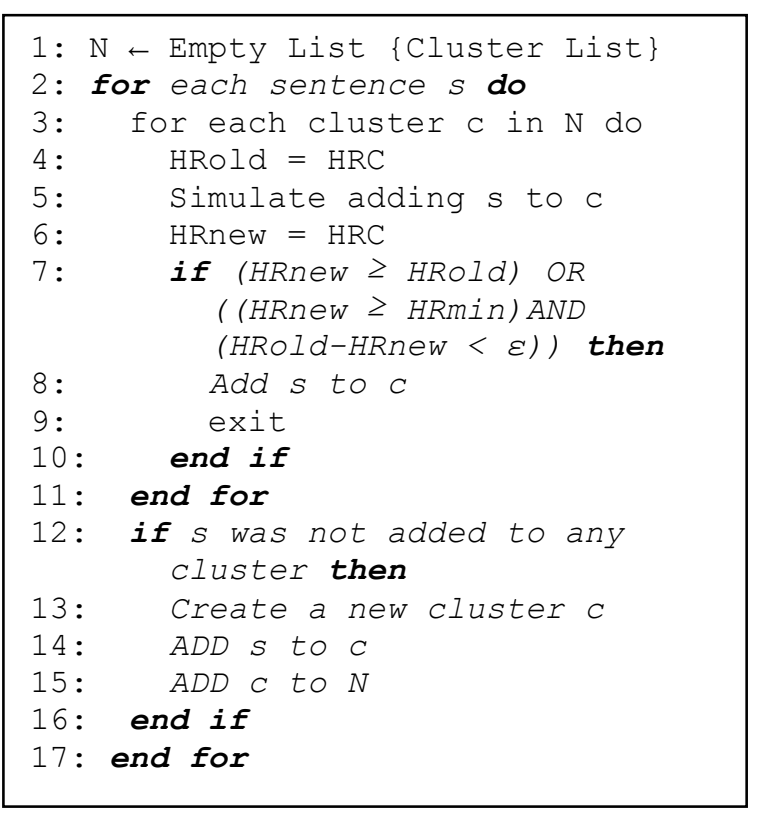

Gambar 4. Pseudo Code Algoritma SHC. 
memenuhi nilai threshold dan kondisi histogram ratio. Penentuan keanggotaan cluster tersebut mengikuti algoritma SHC seperti pada Gambar 4.

\subsection{Pengurutan Cluster}

Pengurutan cluster dilakukan karena pada proses clustering menggunakan algoritma $S H C$ tidak pernah ada pengetahuan khusus berapa jumlah cluster yang akan terbentuk. Sehingga sangat penting untuk mengetahui cluster-cluster mana saja yang terpilih menjadi kandidat ringkasan akhir (Sarkar, 2009).

Proses pembentukan cluster akan terus berlangsung mengikuti algoritma pada Gambar 4. Pada penelitian ini tidak digunakan parameter untuk menentukan jumlah cluster yang ideal. Seluruh cluster yang terbentuk hanya akan diurutkan dan dipilih sejumlah cluster yang terbaik.

Cluster importance merupakan sebuah metode yang melakukan pengurutan cluster berdasarkan nilai penjumlahan bobot dari kata-kata yang merupakan kata frequent (sering muncul) yang terkandung dalam cluster. Sebuah threshold $(\theta)$ ditetapkan untuk menentukan apakah suatu kata tersebut termasuk kata frequent atau tidak terhadap seluruh dokumen input. Jika frekuensi suatu kata memenuhi threshold $\theta$ maka kata tersebut dianggap sebagai kata yang memiliki bobot. Cluster importance dihitung sesuai dengan Persamaan (2), di mana bobot dari cluster $c$ ke-j dinotasikan dengan $\operatorname{Bobot}\left(c_{j}\right)$.

$$
\operatorname{Bobot}\left(c_{j}\right)=\sum_{w \in c_{j}} \log (1+j u m l a h(w))
$$

Nilai jumlah( $w)$ merupakan jumlah dari kata $w$ pada koleksi input yang bernilai lebih dari atau sama dengan nilai threshold $\theta$. Hasil perhitungan seluruh cluster importance akan diurutkan secara descending dan nantinya akan dipilih sejumlah cluster teratas.

\subsection{Pemilihan Kalimat Representatif}

Pemilihan kalimat yang menjadi kalimat ringkasan dalam penelitian ini didasarkan pada tingginya skor suatu kalimat di dalam suatu cluster tertentu. Penentuan skor kalimat dihitung berdasarkan kombinasi skor fitur SID dan SCK (Suputra, Arifin, \& Yuniarti, 2013). Fitur SID menggunakan pendekatan clustering kalimat sehingga perhitungannya mengacu pada positional text (sentence) graph dalam suatu cluster kalimat (Suputra, Arifin, \& Yuniarti, 2013). Sedangkan fitur SCK mengacu pada kata yang sering muncul dalam suatu cluster kalimat dan jarang/tidak muncul pada cluster kalimat lainnya. Fitur SCK diadopsi dari konsep Term Frequency Inverse Document Frequency (TF.IDF) (Suputra, Arifin, \& Yuniarti, 2013). Perhitungan skor fitur SID, SCK, dan kombinasi keduanya, masing-masing ditunjukkan pada Persamaan (3), Persamaan (4), dan Persamaan (7).

$$
F_{\text {sid }}\left(s_{k j}\right)=\frac{W_{s_{k j}}}{\max _{l \in\{1,2, . ., n\}} W_{s_{l j}}} .
$$

Skor fitur SID dinotasikan dengan $F_{s i d}\left(s_{k j}\right)$ merupakan hasil bagi antara penjumlahan bobot dari semua edge yang datang dari kalimat $s$ ke- $k$ pada cluster ke-j (dinotasikan dengan $W_{s_{k j}}$ ) dengan bobot edge maksimum diantara semua kalimat yang ada pada cluster ke-j (dinotasikan dengan $\max _{l \in\{1,2, ., n\}} W_{s_{l j}}$.

$$
F_{s c k}\left(s_{k j}\right)=\frac{1}{\operatorname{len}\left(s_{k j}\right)} \sum_{w_{i j} \in s_{k j}} t f_{-} i s c f_{w_{i j}} .
$$

Skor fitur SCK untuk setiap kata penyusun kalimat s ke- $k$ yang berada pada cluster kalimat ke-j dinotasikan dengan $F_{s c k}\left(s_{k j}\right)$. Nilai skor fitur $S C K$ merupakan perkalian antara panjang kalimat $s$ ke- $k$ pada cluster kalimat ke-j (dinotasikan dengan len $\left(s_{k j}\right)$ ) dan penjumlahan bobot kata-kata kunci yang didapat dari perhitungan $t f \_i s c f$ pada setiap kalimat. Nilai tf_iscf dapat diketahui berdasarkan Persamaan (5).

$$
t f_{-} i s c f_{w_{i j}}=\frac{t f_{w_{i j}} * i s c f_{w_{i j}}}{\sqrt{\sum_{i=1}^{M}\left(t f_{w_{i j}} * i s c f_{w_{i j}}\right)^{2}}}
$$

Pada Persamaan (5) nilai tf_iscf harus memperhitungkan jumlah kemunculan term $w$ ke- $i$ pada cluster ke-j (dinotasikan dengan $t f_{w_{i j}}$ ) serta inverse sentence cluster frequency term $w$ ke-i pada cluster ke-j (dinotasikan dengan $i s c f_{w_{i j}}$ ). Nilai $i s c f_{w_{i j}}$ dapat dihitung berdasarkan Persamaan (6).

$$
i s c f_{w_{i j}}=\log \left(\frac{N}{s c f_{w_{i j}}}\right) .
$$

Nilai $\operatorname{isc} f_{w_{i j}}$ merupakan hasil logaritma antara jumlah dokumen $\mathrm{N}$ dengan jumlah cluster kalimat yang mengandung kata $w$ ke-i pada cluster kalimat ke-j (dinotasikan dengan $s c f_{w_{i j}}$ ).

$$
\begin{aligned}
& \operatorname{Skor}_{\text {Komb }}\left(S_{k j}\right) \\
& =\lambda \cdot F_{\text {sid }}\left(S_{k j}\right)+(1-\lambda) \cdot F_{s c k}\left(S_{k j}\right)
\end{aligned}
$$

Nilai skor kombinasi antara fitur SID dan fitur $S C K$ dinotasikan dengan $\operatorname{Skor}_{K o m b}\left(s_{k j}\right)$ dan dihitung berdasarkan Persamaan (7). Pada perhitungan skor kombinasi tersebut, notasi $\lambda$ menunjukkan nilai bobot untuk fitur $S I D$, sedangkan 
nila bobot untuk fitur $S C K$ adalah 1- $\lambda$. Nilai parameter $\lambda$ berada pada rentang 0 hingga 1 , dan diatur sesuai pembagian persentase bobot antara fitur SID dan SCK. Semakin besar nilai $\lambda$ menunjukkan bahwa bobot penggunaan fitur SID lebih dominan dibandingkan dengan fitur $S C K$.

\subsection{Penyusunan Ringkasan}

Penyusunan hasil ringkasan pada penelitian ini dilakukan dengan cara melakukan pemilihan kalimat representatif berdasarkan bobot cluster importance yang paling tinggi. Kemudian pemilihan dilanjutkan pada cluster berikutnya sesuai dengan daftar urutan cluster. Pemilihan kalimat tersebut terus dilakukan hingga panjang ringkasan yang diharapkan terpenuhi.

\subsection{Pengukuran Hasil Ringkasan}

Pengukuran hasil peringkasan otomatis yang digunakan pada penelitian ini adalah ROUGE. Metode ini mengukur kualitas hasil ringkasan berdasarkan kesesuaian antara unit-unit ringkasan hasil sistem dengan unit-unit ringkasan referensi yang dibuat secara manual. Pada penelitian ini digunakan metode ROUGE-N. Pengukuran ROUGE$N$ mengukur perbandingan $N$-gram dari dua ringkasan, dan menghitung berapa jumlah yang sesuai. Perhitungan ROUGE- $N$ yang diadopsi dari (Lin, 2004) ditunjukkan pada Persamaan (8).

$$
\begin{aligned}
& \text { ROUGE - N } \\
& =\frac{\sum_{S \in S_{u m m}} \sum_{N-\text { gram }_{\text {S }}} \operatorname{Count}_{\text {match }}(N-\text { gram })}{\sum_{S \in \text { Summ }_{\text {ref }}} \sum_{N-\text { gram }} \operatorname{Count}(N-\text { gram })}
\end{aligned}
$$

Pada Persamaan (8), notasi N menunjukkan panjang


maksimum dari $N$-gram yang muncul pada ringkasan kandidat dan ringkasan sebagai referensi. Count(N-gram) adalah jumlah dari $N$-gram pada ringkasan sebagai referensi. Pada paper ini fungsi $R O U G E-N$ yang digunakan adalah ROUGE dengan nilai $\mathrm{N}=1$ dan $\mathrm{N}=2$. ROUGE dengan nilai $\mathrm{N}=1$ berarti membandingkan kesamaan hasil ringkasan dengan ringkasan referensi untuk setiap satu kata. ROUGE dengan nilai $\mathrm{N}=2$ berarti membandingkan kesamaan hasil ringkasan dengan ringkasan referensi untuk setiap dua kata.

Berdasarkan karakteristik dataset DUC 2004 Task 2 yang menggunakan multiple references summaries (banyak referensi ringkasan) yaitu empat referensi per-cluster dokumen, maka perhitungan nilai ROUGE-N akhir dihitung berdasarkan persamaan (9). Nilai akhir dari ROUGE-N akhir adalah nilai $R O U G E-N$ terbesar yang dihasilkan dari pasangan ringkasan hasil sistem dan ringkasan referensi. Nilai $R O U G E-N$ dihitung pada setiap pasangan ringkasan kandidat $s c$ dan ringkasan referensi rsi. Perhitungan ROUGE-N tersebut diadopsi dari (Lin, 2004) dan ditunjukkan pada Persamaan (9).

$$
\begin{aligned}
& R O U G E-N_{\text {multi }} \\
& =\operatorname{argmax}_{i} R O U G E-N\left(s c, r s_{i}\right)
\end{aligned}
$$

\section{HASIL UJI COBA}

Pengujian dilakukan pada dataset DUC 2004 Task 2 yang dapat diunduh pada alamat http://duc.nist.gov/duc2004/tasks.html. Dataset DUC 2004 Task 2 merupakan kumpulan dokumen berita dalam bahasa Inggris dari Associated Press dan New York Times. Dokumen-dokumen tersebut telah terbagi ke dalam kelompok-kelompok menjadi 50 cluster dokumen. Setiap cluster dokumen terdiri dari rata-rata 10 dokumen berita.

Proses pengujian terdiri atas training dan testing. Proses training dilakukan untuk mengetahui kombinasi parameter yang optimal. Parameterparameter yang diperhitungkan beserta nilai optimalnya ditunjukkan pada Tabel 1.

Proses testing dilakukan untuk menguji kualitas hasil ringkasan berdasarkan kombinasi nilai parameter optimal yang telah dihasilkan pada proses training. Tabel 2 menunjukkan perbandingan hasil pengukuran ROUGE-1 dan ROUGE-2 rata-rata terhadap metode peringkasan multi dokumen yang dikembangkan oleh (Suputra, Arifin, \& Yuniarti, 2013), metode Local Importance Global Importance (LIGI), dan metode yang diusulkan (Semantic Clustering). Hasil pengujian pada Tabel 2 merupakan rata-rata nilai $R O U G E$ dengan parameter $\lambda$ diatur secara bertahap dari 0 sampai 1 .

Pada penelitian ini, juga didapatkan hasil bahwa penggunaan jumlah elemen diagonal $k$ pada matriks singular $\sum$ memberikan pengaruh pada hasil pengujian nilai ROUGE-1 dan ROUGE-2.

\begin{tabular}{|c|c|c|}
\hline Parameter & Keterangan & $\begin{array}{c}\text { Nilai } \\
\text { Optimal }\end{array}$ \\
\hline$H R_{\text {min }}$ & $\begin{array}{l}\text { Batas nilai minimum } \\
\text { Histogram Ratio }\end{array}$ & 0,7 \\
\hline$\varepsilon$ & 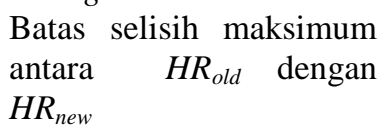 & 0,3 \\
\hline$S_{T}$ & $\begin{array}{l}\text { Batas similarity bin pada } \\
\text { perhitungan histogram } \\
\text { ratio }\end{array}$ & 0,5 \\
\hline$\theta$ & $\begin{array}{l}\text { Batas frekuensi minimal } \\
\text { kata } w \text { dalam proses } \\
\text { pengurutan cluster }\end{array}$ & 10 \\
\hline$\alpha$ & $\begin{array}{l}\text { Nilai threshold untuk } \\
\text { menentukan } \\
\text { pembentukkan edge antar } \\
\text { kalimat pada fitur SID }\end{array}$ & 0,4 \\
\hline$\lambda$ & $\begin{array}{l}\text { Bobot untuk fitur SID dan } \\
\text { fitur } S C K\end{array}$ & $0-1$ \\
\hline
\end{tabular}
Pengujian dilakukan pada beberapa dokumen dengan nilai $k=75, k=100, k=125$, dan $k=150$. Hasil

Tabel 1. Kombinasi Parameter Uji Optimal 
Tabel 2.Hasil Pengukuran ROUGE-1 dan ROUGE-2

\begin{tabular}{lcc}
\hline Metode & ROUGE-1 & ROUGE-2 \\
\hline Suputra & 0,390 & 0,104 \\
LIGI & 0,374 & 0,096 \\
Semantic Clustering & 0,395 & 0,106 \\
\hline
\end{tabular}

pengujian rata-rata pada beberapa dokumen dengan nilai $k$ yang beragam ditunjukkan pada Gambar 5 .

\section{PEMBAHASAN HASIL UJI COBA}

Hasil pengujian yang dilakukan pada proses training menghasilkan kombinasi parameter yang optimal, masing-masing $H R_{\text {min }}=0,7, \varepsilon=0,3, S_{T}=0,5$, $\theta=10$, dan $\alpha=0,4$. Sedangkan nilai $\lambda$ diujikan pada nilai 0 sampai dengan 1 terhadap kombinasi parameter optimal tersebut. Kombinasi parameter tersebut memberikan nilai ROUGE-1 dan ROUGE-2 tertinggi untuk peringkasan multi dokumen pada penelitian ini.

Pengujian pada proses testing dengan menggunakan kombinasi parameter optimal, menunjukkan bahwa metode Semantic Clustering memiliki nilai ROUGE-1 lebih tinggi dari pada metode lainnya. Hasil yang dicapai oleh metode Semantic Clustering memiliki selisih sebesar 0,00446 dengan metode Suputra atau meningkat sebesar $1,14 \%$. Hasil tersebut juga memiliki selisih sebesar 0,02056 dengan metode LIGI atau meningkat sebesar 5,49\%. Perbandingan hasil yang diperoleh menunjukkan bahwa metode yang diusulkan mampu melakukan perbaikan pada metode terdahulu untuk pengukuran kualitas dengan ROUGE-1.

Pengukuran dengan menggunakan ROUGE-2 juga menunjukkan keunggulan metode Semantic Clustering dibanding dengan metode lain. Hasil yang dicapai oleh metode Semantic Clustering memiliki selisih sebesar 0,00205 dengan metode Suputra atau meningkat sebesar 1,97\%. Hasil tersebut juga memiliki selisih sebesar 0,00955 dengan metode LIGI atau meningkat sebesar 9,89\%.

Hasil pengujian menunjukkan bahwa

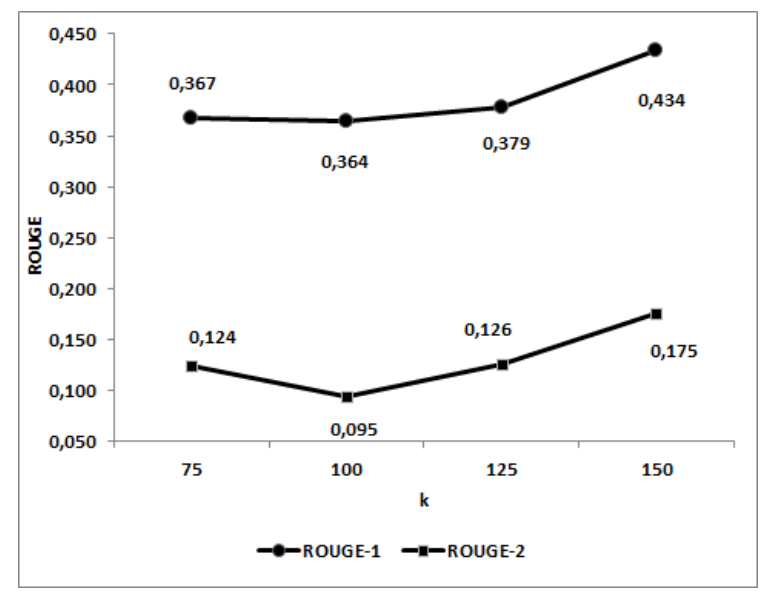

Gambar 5. Pengaruh Nilai $k$ Terhadap Nilai ROUGE. pengukuran kualitas ringkasan yang hanya membandingkan satu kata saja (uni gram) memiliki nilai lebih tinggi jika membandingkan dua kata (bigram). Hal tersebut ditunjukkan dengan nilai ROUGE-1 rata-rata yang lebih tinggi dari nilai ROUGE-2 rata-rata. Hasil ini dapat dengan mudah dipahami, misalnya dengan contoh bahwa lebih banyak hasil yang sama jika menggunakan kata party atau leaders saja dibanding menggunakan gabungan kata party leaders.

Keunggulan nilai yang diperoleh pada metode Semantic Clustering disebabkan oleh kemampuan metode tersebut untuk menemukan relasi semantik pada pembuatan cluster kalimat. Kemampuan itu dimungkinkan dengan penggunaan LSI sebelum mengukur nilai similaritas kalimat. Pada metode Suputra, nilai similaritas diukur dengan menggunakan Uni Gram Matching Based Similarity. Metode pengukuran tersebut hanya mempertimbangkan jumlah kata yang dipakai bersama oleh kedua kalimat yang dibandingkan. Sedangkan dalam kenyataannya, banyak kata yang memiliki makna yang sama tetapi bentuk yang berbeda (sinonim). Salah satu contoh yang dapat menjelaskan konsep sinonim adalah kata car dan automobile. Kedua kata tersebut memiliki makna yang sama tetapi bentuk kata yang berbeda. Jika kedua kata tersebut diukur menggunakan metode Uni Gram Matching Based Similarity, maka nilai similaritasnya rendah. Akan tetapi jika diukur menggunakan konsep semantic similarity, maka similaritasnya tinggi.

Penggunaan LSI pada proses pembentukan cluster kalimat mampu menemukan kata-kata yang sering dipakai pada konsep yang sama. Dengan demikian hasil ringkasan yang diperoleh lebih mendekati hasil peringkasan manusia. Kedekatan tersebut ditunjukkan oleh nilai ROUGE yang lebih tinggi.

Pada penelitian ini juga didapatkan hasil bahwa penggunaan nilai bobot pada fitur SID dan SCK tidak mempengaruhi secara signifikan kualitas hasil ringkasan. Hal tersebut ditunjukkan dengan nilai ROUGE yang cenderung tetap walaupun menggunakan nilai parameter $\lambda$ yang bervariasi dari 0 hingga 1. Metode Semantic Clustering memungkinkan pemberian nilai bobot untuk fitur $S I D$ dan SCK yang sama untuk keduanya.

Penggunaan jumlah elemen diagonal $k$ pada matriks singular $\sum$ juga memperlihatkan adanya pengaruh pada nilai $R O U G E-1$ dan ROUGE-2. Nilai ROUGE-1 dan ROUGE-2 mengalami penurunan pada penggunaan nilai $k=75$ hingga $k=100$, kemudian mengalami kenaikan pada penggunaan nilai $k=100$ hingga $k=150$. Nilai $k$ menentukan jumlah elemen singular yang digunakan untuk proses perhitungan similarity kalimat pada tahapan pembentukan cluster kalimat. Pengurangan nilai $k$ dapat mereduksi dimensi data yang diolah, namun pada jumlah tertentu justru menghilangkan informasi 
penting yang terkandung pada dokumen yang diolah. Berdasarkan temuan tersebut, nilai $k$ perlu diatur sedemikian agar mampu menghasilkan hasil peringkasan dengan nilai ROUGE yang tinggi walaupun terjadi reduksi dimensi data.

\section{KESIMPULAN}

Teknik semantic clustering dan pemilihan kalimat representatif cluster dapat diimplementasikan pada peringkasan multi dokumen. Implementasi tersebut dilakukan dengan memanfaatkan prinsip kerja LSI dan SHC untuk pembentukan cluster kalimat secara semantik, serta mengkombinasikan fitur SID dan SCK untuk pemilihan kalimat representatif cluster.

Hasil pengujian metode yang diusulkan mampu mencapai nilai ROUGE-1 sebesar 0,395 dan ROUGE-2 sebesar 0,106. Nilai ROUGE-1 metode yang diusulkan lebih tinggi $1,14 \%$ dari metode Suputra dan 5,49\% dari metode LIGI. Sedangkan nilai $R O U G E-2$ metode yang diusulkan lebih tinggi $1,97 \%$ dari metode Suputra dan $9,89 \%$ dari metode LIGI. Dengan demikian metode yang diusulkan layak untuk diimplementasikan pada peringkasan multi dokumen.

Metode yang diusulkan mampu menemukan hubungan semantik tersembunyi antar kata. Hal tersebut dapat meningkatkan koherensi cluster kalimat. Namun demikian, metode LSI yang digunakan untuk tujuan tersebut menggunakan bantuan dekomposisi matriks SVD. Pada proses dekomposisi $S V D$, jumlah elemen diagonal $k$ matriks singular $\sum$ memberikan pengaruh pada nilai pengujian ROUGE-1 dan ROUGE-2. Pengurangan nilai $k$ tersebut dapat mereduksi dimensi data, namun pada nilai tertentu menurunkan hasil pengujian ROUGE-1 dan ROUGE-2. Sehingga penelitian ini dapat dikembangkan lebih lanjut untuk menentukan nilai $k$ yang paling optimal untuk digunakan agar hasil pengujian ROUGE-1 dan $R O U G E-2$ berada pada nilai tertinggi.

\section{DAFTAR PUSTAKA}

GUPTA, V. \& Lehal, G. S. 2010. A Survey of Text Summarization Extractive Techniques. Journal of Emerging Technologies in Web Intelligence, vol. II, no. 3, pp. 258-268.

HAMMOUDA, K. M. \& KAMEL, M. S. 2003. Incremental Document Clustering Using Cluster Similarity Histograms. Proceeding of the 2003 IEEE/WIC International Conference on Web Intelligence.

HE, T., LI, F., SHAO, W., CHEN, J. \& L. MA, L. 2008. A New Feature-Fusion Sentence Selecting Strategy for Query-Focused Multi-Document Summarization. International Conference on Advanced Language Processing and Web Information Technology.
KOGILAVANI, A. \& BALASUBRAMANI, P. 2010. Clustering and Feature Spesific Sentence Extraction Based Summarization of Multiple Documents. International journal of computer science \& information Technology, vol. II, no. 4.

LIN, C.Y. 2004. ROUGE: A Package for Automatic Evaluation of Summaries. Proceedings of Workshop on Text Summarization Brances Out.

OUYANG, Y., Li, W., Zhang, R. , Li, S. \& Lu, Q. 2012. A Progressive Sentence Selection Strategy for Document Summarization. Information Processing and Management.

SARKAR, K. 2009. Sentence Clustering-based Summarization of Multiple Text Documents. International Journal of Computing Science and Communication Technologies, vol. II, no. 1.

SONG, W. \& PARK, S.C., 2004. Genetic Algorithm for Text Clustering Based on Latent Semantic Indexing. Computers and Mathematics with Applications, pp. 19011907.

SUPUTRA , I.P.G., H., ARIFIN, A. Z. \& YUNIARTI, A. 2013. Pendekatan Positional Text Graph Untuk Pemilihan Kalimat Representatif Cluster Pada Peringkasan Multi-Dokumen. Jurnal Ilmu Komputer, vol. IV, no. 2. 